\title{
ANALISIS POLA KONSUMSI SAYUR DAN BUAH DENGAN PERKEMBANGAN MOTORIK HALUS ANAK DI PAUD TERPADU NUSA INDAH KOTA PAREPARE
}

\section{Analyze Between Consumption of Vegetable and Fruit with Soft Motor Development Of Children in PAUD Nusa Indah Parepare}

\author{
Fitriani Umar ${ }^{1}$, Muhammad Nur Maallah ${ }^{2}$ \\ ${ }^{1}$ Fakultas Ilmu Kesehatan Universitas Muhammadiyah Parepare \\ ${ }^{2}$ Fakultas Agama Islam Universitas Muhammadiyah Parepare \\ (fitrah.gizi@gmail.com) \\ (muhammadnurmaallah@gmail.com)
}

\begin{abstract}
ABSTRAK
Prevalensi kurang konsumsi sayur dan buah pada anak usia prasekolah cukup signifikan. Kurangnya konsumsi zat gizi pada anak berpengaruh terhadap tumbuh kembangnya. Tujuan dari penelitian ini untuk mengetahui pengaruh pola konsumsi sayur dan buah terhadap perkembangan motorik halus anak di PAUD Terpadu Nusa Indah Kota Parepare. Jenis penelitian yang digunakan adalah observasional analitik dengan pendekatan Cross Sectional Study. Sampel adalah seluruh anak didik usia 3-6 tahun di PAUD Terpadu Nusa Indah Kota Parepare. Pengambilan sampel dilakukan dengan metode total sampling sebanyak 50 orang. Hasil penelitian diperoleh berdasarkan frekuensi, $82 \%$ anak sering mengkonsumsi sayur dan buah namun berdasarkan jumlah asupan, $100 \%$ anak memiliki jumlah asupan kurang. Hasil analisis menunjukkan ada pengaruh frekuensi konsumsi sayur dan buah dengan perkembangan motorik halus anak $(\mathrm{p}=0,015)$. Disarankan perlunya perhatian dan peran orang tua dalam meningkatkan jumlah konsumsi sayur dan buah pada anak.
\end{abstract}

Kata Kunci : Perkembangan motorik halus, sayur dan buah

\section{ABSTRACT}

Prevalence of less consumption of vegetables and fruits in preschool children is significant. Lact of nutrient consumption in children has been effect on their growth. The purpose of this study to determine the influence of consumption pattern of vegetables and fruits to the soft motor development of children in PAUD Nusa Indah Parepare. The type of research used is observational analytic with cross sectional study approach. Samples are all children aged 3-6 years in PAUD Terpadu Nusa Indah Parepare. Results of the study were obtained $82 \%$ of children often consumed vegetables and fruits, but base on amount of intakes, $100 \%$ of children have less intake. The result showed that there was a correlation of frequency consumption of vegetables and fruits with soft motor development $(p=0,015)$. It is suggest that the attention and role of parents in increasing amount of consumption of vegetables and fruits in children

Keyword : Soft motor developments, vegetables and fruits 



\section{PENDAHULUAN}

Masa anak berusia di bawah lima tahun (balita) merupakan periode penting tumbuh kembang anak yang kemudian akan menjadi dasar dan menentukan perkembangan anak selanjutnya. Salah satu aspek perkembangan anak yang perlu diperhatikan yaitu kemampuan motorik. ${ }^{1}$ Permasalahan gizi yang dialami anak berusia balita dapat mengakibatkan terhambatnya perkembangan anak. Hasil penelitian mengungkapkan bahwa anak yang mengalami hambatan pertumbuhan menjadi tidak aktif, apatis, pasif, dan tidak mampu berkonsentrasi. ${ }^{2}$

Usia anak pra sekolah (3-6 tahun) adalah usia emas dimana pada masa ini perkembangan fisik dan psikologisnya sangat pesat sehingga butuh nutrisi yang baik dan seimbang. Anak usia pra sekolah mempunyai sifat konsumtif aktif yaitu bisa memilih makanan yang disukainya sedangkan ibu tidak begitu memperhatikan makanannya dengan anggapan anak sudah bisa makan sendiri. ${ }^{3}$ Hasil observasi yang dilakukan sebelumnya diperoleh bahwa sebagian besar anak memiliki kebiasaan makan yang kurang baik. Mereka cenderung lebih banyak mengkonsumsi susu, makanan jajanan dan kurang mengkonsumsi sayur dan buah.

Konsumsi sayur dan buah orang Indonesia masih relatif rendah, padahal Indonesia merupakan negara agraris dengan komoditi sayur dan buah lokal yang melimpah. Kurangnya konsumsi sayur dan buah di Indonesia hampir merata disetiap provinsi termasuk di Sulawesi Selatan. Berdasarkan Riset Kesehatan Dasar (Riskesdas) Tahun 2013 diperoleh informasi bahwa 96\% masyarakat Sulawesi Selatan umur $>10$ tahun kurang mengkomsumsi sayur dan buah. ${ }^{4}$ Prevalensi kurang konsumsi sayur pada anak usia prasekolah cukup signifikan. Hasil Penelitian Irene Ayu Indira pada anak pra sekolah di Toraja Utara menemukan bahwa sayur yang dikonsumsi anak tidak sesuai dengan jumlah standar rekomendasi Kemenkes. Rata-rata ibu hanya memberi anak 1-3 sendok makan sayur dan tidak rutin, sedangkan buah jarang dikonsumsi. ${ }^{5}$ Untuk usia 3-6 tahun dibutuhkan 4-5 porsi sayuran perhari rutin dalam seminggu atau setara dengan 250 gram perhari. ${ }^{6}$

Sayur dan buar merupakan sumber zat gizi mikro yang sangat penting dalam proses metabolisme tubuh sebagai zat pengatur. Asupan zat gizi yang penting untuk fungsi motorik meliputi energi, protein, besi dan seng. Beberapa hasil penelitian menggambarkan bahwa perkembangan motorik halus sangat berkaitan dengan status gizi anak. Gagal tumbuh yang terjadi akibat kurang gizi pada masa-masa emas akan berakibat buruk pada kehidupan berikutnya yang sulit diperbaiki. ${ }^{7}$ Berdasarkan latar belakang tersebut, peneliti tertarik untuk melihat apakah ada pengaruh pola konsumsi sayur dan buah dengan perkembangan motorik halus pada anak di PAUD Terpadu Nusa Indah Kota Parepare 


\section{BAHAN DAN METODE}

Jenis penelitian yang digunakan adalah observasional analitik dengan pendekatan Cross Sectional Study. Penelitian dilaksanakan di PAUD Terpadu Nusa Indah Kota Parepare pada bulan Maret hingga April 2018. Populasi dalam penelitian ini adalah seluruh anak peserta didik di PAUD Terpadu Nusa Indah Kota Parepare. Sampel adalah peserta didik usia 3-6 tahun di PAUD Terpadu Nusa Indah. Pengambilan sampel dilakukan dengan metode total sampling sebanyak 50 orang.

Pengumpulan data primer berupa perkembangan motorik halus anak diukur dengan menggunakan tes skrining perkembangan menurut Denver II. Item-item pengukuran motorik halus antara lain membuat menara dari 2-8 kubus, meniru membuat garis vertikal, menggoyangkan ibu jari, mencontoh garis silang, menggambar orang 3 bagian, mencontoh membuat lingkaran, memilih garis yang lebih panjang, dan mencontoh membuat gambar persegi.

Data pola konsumsi sayur dan buah anak diperoleh dengan melakukan wawancara pada pengasuh atau ibu anak dengan menggunakan formulir recall 24 jam dan food frequency. frekuensi konsumsi sayuran dan buah dikatakan sering jika dikonsumsi minimal 2-4 kali perminggu sedangkan jumlah konsumsi sayuran dan buah dikatakan cukup jika jumlah konsumsi minimal $250 \mathrm{gr} / \mathrm{hari}$ berturut-turut dalam seminggu. Data sekunder berupa informasi data anak diperoleh di Paud Terpadu
Nusa Indah. Pengolahan data menggunakan Program SPSS dan Nutrisurvey 2007. Analisis data dilakukan dengan menggunakan uji Fisher Exact Test. Data disajikan dalam bentuk tabel distribusi frequensi disertai narasi.

\section{HASIL}

Tabel 1 menggambarkan karakteristik anak yang menjadi sampel penelitian. Berdasarkan jenis kelamin proporsi tertinggi adalah anak yang berjenis kelamin laki-laki (52\%) sedangkan perempuan sebanyak $48 \%$. Berdasarkan umur, sebagian besar anak berumur 6 tahun (34\%) dan yang berumur 3 tahun sebanyak 20\%. Berdasarkan tingkat pendidikan ibu, sebagian besar berpendidikan Diploma/Sarjana (78\%), sedangkan yang terendah adalah yang tidak sekolah sebanyak $2 \%$. Menurut jenis pekerjaan, $38 \%$ ibu bekerja sebagai Pegawai Negeri Sipil sedangkan proporsi terendah adalah yang bekerja sebagai wiraswasta sebanyak $2 \%$

Tabel 2 menunjukkan distribusi variabel yang diteliti. Berdasarkan tabel terlihat bahwa $70 \%$ anak memiliki perkembangan motorik halus tergolong normal, sedangkan yang tidak normal sebanyak $30 \%$. Berdasarkan frekuensi konsumsi sayur dan buah diperoleh $82 \%$ anak tergolong sering mengkonsumsi sayur dan buah sedangkan berdasarkan jumlah asupan, $100 \%$ anak memiliki asupan sayur dan buah dalam jumlah kurang atau dibawah standar yang dianjurkan . 
Tabel 3 menggambarkan pengaruh pola konsumsi sayur dan buah terhadap perkembangan motorik halus anak. Berdasarkan tabel terlihat bahwa responden yang memiliki perkembangan motorik halus yang tidak normal $66,7 \%$ jarang mengkonsumsi sayur dan buah sedangkan responden yang memiliki perkembangan motorik halus normal $78 \%$ memiliki frekuensi konsumsi sayur dan buah dengan kategori sering. Hasil analisis dengan menggunakan uji fisher exact test diperoleh ada pengaruh frekuensi konsumsi sayur dan buah dengan perkembangan motorik halus anak $(\mathrm{p}=0,015)$.

\section{PEMBAHASAN}

Konsumsi sayur dan buah merupakan sumber zat gizi mikro yang sangat bermanfaat bagi tubuh karena kedua komponen gizi tersebut sangat penting dalam proses metabolisme tubuh sebagai zat pengatur juga bermanfaat menurunkan insiden terkena penyakit kronis. Sayur merupakan makanan penting yang harus selalu dikonsumsi setiap kali makan, tidak hanya bagi orang dewasa, mengkonsumsi sayur sangat penting untuk dikonsumsi sejak usia anak-anak terutama pada anak usia prasekolah yakni 3-6 tahun, karena pada usia tersebut merupakan masa emas untuk pertumbuhan dan perkembangan bagi anak-anak. ${ }^{8}$

Hasil penelitian diperoleh $82 \%$ anak memiliki kebiasaan mengkonsumsi sayur dan buah dalam frekuensi sering namun berdasarkan jumlah asupan, 100\% anak mengkonsumsi sayur dan buah dalam jumlah kurang atau tidak sesuai dengan anjuran. Data yang diperoleh dari hasil wawancara, umumnya jenis sayur yang dikonsumsi adalah sayur sup (wortel dan kentang) dikonsumsi 5-6 kali/minggu, bayam, kangkung, jagung dan nangka umumnya dikonsumsi 2-4 kali/minggu. Jenis buah yang sering dikonsumsi adalah apel, pepaya dan rambutan (2-4 kali/minggu) . Dilihat dari jumlah asupan, rata-rata konsumsi sayur anak hanya 1-3 sendok makan dan buah umumnya sangat sedikit.

Hasil penelitian ini sejalan dengan penelitian Irine Ayu Indira yang menyatakan bahwa anak pra sekolah hanya mengkonsumsi 1-3 sendok makan sayur dan buah sangat jarang, biasanya anak hanya memakan lauk lain yang tersedia seperti telur, daging dan ikan sedangkan sayur yang telah diberikan tidak dimakan bahkan terkadang anak memuntahkannya. Tak bisa dipungkiri perilaku konsumsi sayur dan buah anak sangat dipengaruhi juga pada apa yang tersedia di rumah, dan penyediaan konsumsi tersebut pastinya memiliki acuan ataupun panutan. Biasanya orangtua menjadi panutan dalam penyediaan konsumsi sayur dan buah di rumah. ${ }^{6}$

$$
\text { Hasil penelitian Ogunba }
$$
menyebutkan bahwa perilaku ibu yang benar selama memberi makan akan meningkatkan konsumsi pangan anak dan pada akhirnya akan meningkatkan status gizi anak. Makanan dan minuman bergizi harus dapat disediakan orang tua bahkan sejak masa prenatal (sebelum 
kelahiran) hingga pada masa postnatal (setelah kelahiran), periode usia bayi, balita, usia prasekolah, usia sekolah hingga periode usia dewasa. ${ }^{9}$

Hasil penelitian ini juga sejalan dengan penelitian Hanum (2012) dimana sayuran ratarata hanya dikonsumsi $3 \mathrm{kali} /$ minggu pada kelompok balita Sedangkan konsumsi buah pada kedua kelompok balita hampir sama hanya 2 kali/minggu. Rendahnya konsumsi buah berdasarkan pengamatan pada kedua kelompok dipengaruhi oleh daya beli dan ketersediaan buah yang rendah. ${ }^{10}$

Terdapat variasi pemberian makanan balita (2-5 tahun), anak telah mempunyai motorik halus ketika berusia dua tahun, oleh karena itu pada usia ini anak dibiasakan untuk memegang sendok makan dan gelas minumnya sendiri, belajar memasukkan makanan kedalam mulut dan mengunyahnya dengan baik. Kebiasaaan makanan yang beragam, bergizi dan berimbang, harus dibiasakan sejak usia dini. Pemberian makanan yang baik akan membentuk kebiasaaan makanan yang baik pula pada anak. ${ }^{11}$

Keadaan lingkungan dan sikap keluarga merupakan pertimbangan yang penting dalam pemberian makan kepada anak, karena pada perkembangan anak, keluarga dapat membantu anak mencapai sikap normal dan berminat terhadap makanan tanpa adanya suatu kecemasan dan kekuatiran mengenai makan. Hawadi (2001) menyatakan bahwa anak yang berumur 2- 5 tahun umumnya sudah mampu makan makanan biasa dan tidak pedas. Mereka masih tergolong konsumen pasif dan belum dapat memilih dan menilai kulitas makanan. Seringkali masa ini muncul kebiasaan buruk seperti menyukai makanan yang kurang bergizi seperti permen, coklat dan makanan jajanan lainnya yang dapat menyebabkan berkurangnya nafsu makan. Pemberian makanan pada anak bukan sekedar membuat kenyang, tetapi untuk memenuhi kebutuhan zat gizi secara adekuat untuk keperluan hidup mendidik anak untuk membina selera dan kebiasaan makan yang sehat. ${ }^{12}$ Hasil penelitian diperoleh sebagian besar anak masih mengkonsumsi susu formula dan ini menyebabkan konsumsi anak semakin berkurang dan cenderung malas makan. Adanya program pemberian makan pada jam sekolah di sekolah ini cukup membantu anak melengkapi kebutuhan gizinya terutama anak yang masih dominan mengkonsumsi susu. Namun makanan yang diberikan masih disesuaikan dengan kesukaan anak dan belum bervariasi

Dari hasil analisis diperoleh ada hubungan antara frekuensi konsumsi sayur dan buah dengan perkembangan motorik halus pada anak. Sayur dan buah merupakan sumber utama zat gizi mikro. Hasil penelitian menemukan terdapat perbedaan laju pertumbuhan motorik pada anak yang diberi suplementasi energi dan zat gizi mikro. ${ }^{13}$ Klasifikasi zat gizi yang penting bagi fungsi motorik antara lain energi, protein, besi dan 
zink. Beberapa zat gizi yang membantu penyerapan $\mathrm{Fe}$ dan zink antara lain asam askorbat dan sitrat (pepaya, jambu biji, pisang, mangga, pir, jeruk lemon, apel dan lain-lain). $\mathrm{Fe}$ berperan dalam sintesis monoamine, metabolisme energi di neuron, dan sel glia, mielinisasi, sistem neurotransmitter dan metabolisme dopamine. Zink berfunsi dalam pelepasan DNA dan neurotransmiter. ${ }^{14}$ Adanya defisiensi Fe menyebabkan gangguan pembentukan myelin, fungsi neurotransmiter dan gangguan metabolisme otak. ${ }^{15}$

Perkembangan motorik sangat dipengaruhi oleh organ otak. Otak mengatur setiap gerakan yang dilakukan anak. Sereblum berperan penting dalam menentukan saat aktifitas motorik halus dari penglihatan kemudian diterjemahkan dengan menirukan apa yang anak lihat. Kekurangan gizi secara kuantitas dan kualitas menyebabkan gangguan pada proses dalam struktur dan fungsi otak sehingga mengakibatkan terganggunya fungsi otak secara permanen. ${ }^{16}$

Hasil penelitian diperoleh $22 \%$ anak yang sering mengkonsumsi sayur dan buah

\section{DAFTAR PUSTAKA}

1. Berk LE. Child development. Boston: Allyn \& Bacon, 2003.

2. Rosidi A, Syamsianah A. Optimalisasi perkembangan motorik kasar dan ukuran antropometri anak balita di Posyandu "Balitaku Sayang" Kelurahan Jangli Kecamatan Tembalang Kota Semarang. Seminar hasil-hasil penelitian LPPM Universitas Muhammadiyah Semarang. Semarang, 15 Agustus 2012. namun memiliki kemampuan motorik halus tidak normal. Hal ini dimungkinkan bahwa keterlambatan motorik halus juga dipengaruhi oleh kurangnya stimulus yang diberikan. Stimulus orang tua yang diberikan kepada anak secara rutin akan mampu meningkatkan kemampuan anak untuk memenuhi kebutuhannya secara mandiri seperti memilih dan memakai baju sendiri. ${ }^{17}$

\section{KESIMPULAN DAN SARAN}

$82 \%$ anak memiliki konsumsi sayur dan buah dengan frekuensi sering namun berdasarkan jumlah asupan, 100\% anak memiliki jumlah asupan kurang dari anjuran. Ada pengaruh frekuensi konsumsi sayur dan buah dengan perkembangan motorik halus anak $(\mathrm{p}=0,015)$. Disarankan perlunya perhatian dan peran orangtua dalam membiasakan dan meningkatkan jumlah konsumsi sayur dan buah serta perlunya peran sekolah dalam memberikan edukasi tentang pentingnya konsumsi sayur dan buah pada anak melalui penyediaan makanan yang bergizi dan seimbang.

3. Lida K.S.. Hubungan Pola makan dan status gizi anak pra sekolah di Paud Tunas Mulia Claket Kecamatan Pacet Mojokerto. Midwiferia 2015; Vol1; No. 2

4. Kemenkes. Riset Kesehatan Dasar. Jakarta: Badan Penelitian dan Pengembangan Kesehatan; 2013

5. Kemenkes RI. Pedoman Gizi Seimbang. 2014

6. Irene A. I, Perilaku Konsumsi Sayur Dan Buah Anak Prasekolah Di Desa Embatau Kecamatan Tikala Kabupaten 
Toraja Utara. Jurnal Media Kesehatan Masyarakat Indonesia.

7. Tayong S. N. Hubungan Derajat Stunting dengan Perkembangan Motorik Halus Anak Usia 1224 Bulan. Di Program Studi Kesehatan Masyarakat Universitas Wiralodra. , 2016

8. Santoso \& Ranti,. Kesehatan dan Gizi. Jakarta : Rineka Cipta; 2009.

9. Ogunba BO.. Maternal behavioral feeding practices and under-five nutrition: implication for child development and care. Journal of Applied Sciences Research. 2006; 2(12): 1132-1136

10. Hanum . Pola asuh makan, perkembangan bahasa dan kognitif pada anak balita stunted dan normal di kelurahan sumur batu bantar gebang bekasi. Skripsi intitut pertanian bogor

11. Hastuti D. 2008. Pengasuhan : Teori dan Prinsip serta aplikasi di Indonesia. Bogor: Fakultas Ekologi Manusia, Institut Pertanian Bogor. 2012.

12. Hawadi RA. Psikologi Perkembangan Anak, Mengenal Sifat, Bakat dan Kemampuan Anak. Jakarta : Grasindo; 2001.
13. Kartika L. Faktor-faktor yang mempengaruhi Kemampuan motorik anak usia 12-18 bulan di keluarga miskin dan tidak miskin jurnal Penelitian Gizi dan Makanan 2002; 25 :38-48.

14. Susanty, N \& Margawaty. Hubungan Derajat Stunting, Asupan Zat Gizi dan Sosial Ekonomi Rumah Tangga Dengan Perkembangan Motorik Anak Usia 24-36 Bulan Di Wilayah Kerja Puskesmas Bugangan Semarang. Jurnal of Nutrition College 2012; Vol 1 hal 683-699.

15. Sunartini. Deteksi Gangguan Perkembangan Otak dan Pengembangan Potensi Anak dengan Kemampuan dan Kebutuhan Khusus. Jurnal Fakultas Kedokteran Universitas Gajah Mada Yogyakarta. 2002.

16. Almatsier. Prinsip Dasar Ilmu Gizi. Jakarta : Gramedia Pustaka. 2003.

17. Endah H. M. Hubungan Status Gizi Dengan Perkembangan Motorik Halus pada Anak Usia 3-5 Tahun di Puskesmas Miri Sragen. Stikes Kusuma Husada Surakarta 2015. 


\section{LAMPIRAN}

Tabel 1. Distribusi Karakteristik Responden Berdasarkan Jenis kelamin, Umur, Pendidikan dan Pekerjaan Ibu di PAUD Terpadu Nusa Indah Kota Parepare

\begin{tabular}{lcc}
\hline \multicolumn{1}{c}{ Karakteristik } & Frekuensi (f) & Persen (\%) \\
\hline Jenis Kelamin & & \\
Laki-laki & 26 & 52,0 \\
Perempuan & 24 & 48,0 \\
\hline Umur (Tahun) & & \\
3 & 11 & 22,0 \\
4 & 10 & 20,0 \\
5 & 13 & 26,0 \\
6 & 16 & 32,0 \\
\hline Pendidikan Ibu & & \\
Tidak Sekolah & 1 & 2,0 \\
SMA & 10 & 20,0 \\
Diploma/Sarjana & 39 & 78,0 \\
\hline Pekerjaan Ibu & & \\
Pegawai Negeri Sipil & 19 & 38,0 \\
Karyawan Swasta & 7 & 14,0 \\
Honorer & 6 & 12,0 \\
IRT & 17 & 34,0 \\
Wiraswasta & 1 & 2,0 \\
\hline \multicolumn{1}{c}{ Jumlah } & 50 & 100,0 \\
\hline
\end{tabular}

Sumber : Data Primer, 2018

Tabel 2. Distribusi Responden Berdasarkan Perkembangan Motorik Halus dan Pola Konsumsi Sayur dan Buah di PAUD Terpadu Nusa Indah Kota Parepare

\begin{tabular}{lcc}
\hline \multicolumn{1}{c}{ Variabel } & Frekuensi (f) & Persen (\%) \\
\hline Perkembangan Motorik Halus & & \\
$\quad$ Tidak Normal & 15 & 30,0 \\
$\quad$ Normal & 35 & 70,0 \\
\hline Frekuensi Konsumsi Sayur dan Buah & & \\
$\quad$ Jarang & 9 & 18,0 \\
Sering & 41 & 82,0 \\
\hline Jumlah Konsumsi Sayur dan buah & 50 & 100,0 \\
$\quad$ Kurang & 0 & 0 \\
Cukup $\quad 50$ & 100,0 \\
\hline$\quad$ Jumlah &
\end{tabular}

Sumber : Data Primer, 2018 
Tabel 3. Hubungan Frekuensi Konsumsi Sayur Dan Buah Dengan Perkembangan Motorik Halus Pada Anak Di Paud Terpadu Nusa Indah Kota Parepare

\begin{tabular}{|c|c|c|c|c|c|c|c|}
\hline \multirow{3}{*}{$\begin{array}{l}\text { Frekuensi } \\
\text { Konsumsi Sayur } \\
\text { dan buah }\end{array}$} & \multicolumn{4}{|c|}{ Perkembangan motorik halus } & \multirow{2}{*}{\multicolumn{2}{|c|}{ Total }} & \multirow{3}{*}{$P$} \\
\hline & \multicolumn{2}{|c|}{ Tidak normal } & \multicolumn{2}{|c|}{ Normal } & & & \\
\hline & $\mathrm{n}$ & $\%$ & $\mathrm{n}$ & $\%$ & $\mathrm{n}$ & $\%$ & \\
\hline $\begin{array}{l}\text { Jarang } \\
\text { Sering }\end{array}$ & 6 & 66,7 & 3 & 33,3 & 9 & 100,0 & \multirow{3}{*}{0,015} \\
\hline sermg & 9 & 22,0 & 32 & 78,0 & 41 & 100,0 & \\
\hline Total & 15 & 30,0 & 35 & 70,0 & 50 & 100,0 & \\
\hline
\end{tabular}

Sumber : Data Primer, 2018 